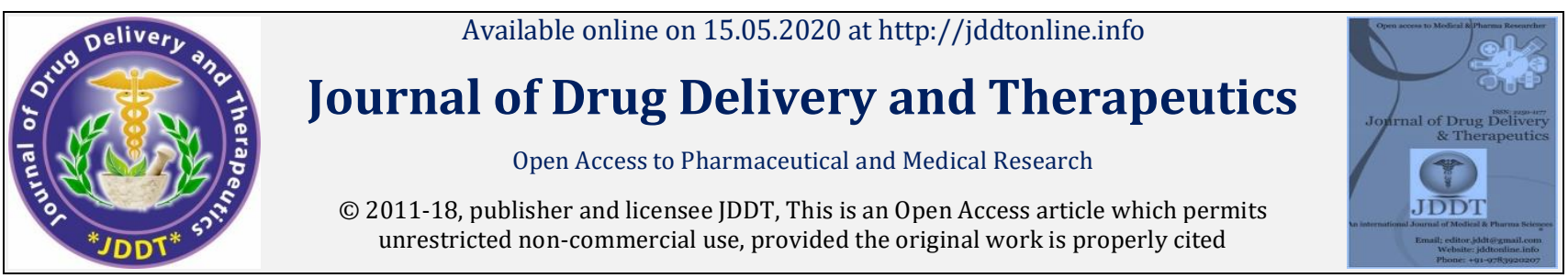

Open $\odot$ Access

Mini Review

\title{
Interferon: Role in health, current trends and therapeutic potentials
}

\author{
Uchendu Ikenna Kingsley*, Ojiako Nkiruka Peace \\ Department of Medical Laboratory Science, College of Medicine, University of Nigeria, Enugu, Nigeria
}

\begin{abstract}
This mini review presents the current trends and topical issues on interferon. This article illustrates the theoretical background and details about interferon, its mechanism of action or roles in the prevention of microbial- or pathogenic disease progression, types and classes, and their therapeutic potentials. All the reported applications have shown that interferon has found its application in gene manipulation and expression of gene products; immunological techniques, viral disease treatment and in the treatment of cancers.
\end{abstract}

Keywords: Interferon, cancers, cancer therapy, viral infection, viral disease treatment.

Article Info: Received 06 March 2020; Review Completed 21 April 2020; $\quad$ Accepted 27 April 2020; Available online 15 May 2020

Cite this article as:

Uchendu IK, Ojiako NP, Interferon: Role in health, current trends and therapeutic potentials, Journal of Drug Delivery and Therapeutics. 2020; 10(3):227-230 http://dx.doi.org/10.22270/jddt.v10i3.4005

*Address for Correspondence:

Uchendu Ikenna Kingsley, Department of Medical Laboratory Science, University of Nigeria, Enugu State, Nigeria

\section{INTRODUCTION}

When host cells are invaded by several pathogens, which are majorly viruses, bacteria, parasites, and tumour cells inclusive; host cells respond by releasing a group of signaling proteins, known as interferons (IFNs) ${ }^{1-4}$. IFNs are considered to be cytokines which are protein molecules that induce cell-to-cell communication to trigger immunity against invading pathogens. Because of their ability to "interfere" with the process of viral replication and ultimately protecting cells from virus infections, they are named interferon. IFNs also act by: activating cells involved in immunity, such as macrophages and NK cells (natural killer cells); increasing host defenses via inducing foreign antigen uptake and increasing the expression of major histocompatibility complex (MHC) antigens ${ }^{5}$. The production of IFNs and other cytokines cause certain symptoms associated with infections, such as muscle pain, fatigue, fever and flu-like "symptoms" 6 . In humans and animals, over 20 distinct interferon genes and proteins have been identified ${ }^{7}$.

Currently, interferons are categorized as cytokines under the group of interleukins and there are three known types of IFNs namely: alpha $(\alpha)$, beta $(\beta)$, gamma $(\gamma)$ and Lambda $(\lambda)$ interferon. The IFN- $\alpha$ and IFN- $\beta$ are classified under type I sub-class, whereas IFN- $y$ is classified under type II subclass $^{8}$. The IFN- $\lambda$ subtype is poorly understood at this time. After cells have been exposed to foreign antigens or agents, the cells are stimulated to release these IFNs, which then act as functionally modulating proteins, leading to events that protect against the invading agents. In order to obtain a complete antiviral effect, however, other proteins known as

ISSN: 2250-1177

[227] 'effector' proteins must be synthesized and released. Therefore, interferons are generally known as "inducer" molecules because they act on other proteins which trigger an antiviral and/or antiproliferative mechanism9,10. To date interferons are characterized by three key features: antiviral action, immunomodulatory action and an antiproliferative action which have been recently reported 11, 12. Under certain conditions, because of the ability of some IFNs to block cells at a given phase of the cell cycle, investigation of their antitumour activity has become crucial12.

\section{TYPES OF INTERFERON}

\section{Alpha interferon}

Alpha interferon, because it is produced by leukocytes, it is also named 'leukocyte interferon'. It is coded for by 15 genes and 9 pseudogenes found on human chromosome 9 and murine chromosome 413. Each of these genes does not contain any intron (non coding region) but only exons (DNAcoding region) ${ }^{13}$. The production of IFN- $\alpha$ is influenced by the action of external agents such as tumour or eukaryotic cells, or by virus-infected cells; and one crucial point to note is that all these inducers trigger the production of IFN- $\alpha$ by lymphocytes and macrophages.

\section{Beta Interferon}

The beta type (IFN- $ß$ ) was the first interferon to be discovered in 1957 by Isaacs and Lindenmann ${ }^{14}$. Isaacs and Lindenmann observed that the cells exposed to the dead viruses secreted a previously unknown substance which blocked future viral attack. IFN- $\beta$ is also named 'fibroblast 
interferon' because it is produced by fibroblasts and epithelial cells under the action of foreign nucleic acids like viruses or other types. Also, IFN- $\beta$ is coded by a gene docked on human chromosome 915 . In this case, only one gene exists and again there are no introns, therefore the whole gene codes for the protein.

\section{Gamma interferon}

The gamma interferon (IFN-y) belongs to a separate subclass, called type II interferon that is named 'immune interferon'. The IFN- $\gamma$ is produced especially by lymphocytes (activated $\mathrm{T}$ cells); and it can promote macrophage activation, mediate antiviral and antibacterial immunity, enhance antigen presentation, orchestrate activation of the innate immune system, coordinate lymphocyte-endothelium interaction etc. ${ }^{16,17}$. IFN- $\gamma$, like IFN- $\beta$, is also coded by a single gene which, however, is not docked on chromosome 9 , but on chromosome $12^{18,19}$. In addition, it contains 3 introns, which was not the case with The IFN- $\alpha$ and IFN- $\beta^{19}$. These and other features resulted to allocating IFN- $\gamma$ to a separate class which has different characteristics with respect to IFN$\alpha$ and IFN- $\beta$. Interestingly, another unique trait of IFN- $\gamma$ is that it has unstable nature at an acidic $\mathrm{pH}$ and these are very important characteristics, especially as far as interferonbased therapy is concerned.

\section{Lambda interferon}

The lambda interferon (IFN- $\lambda$ ) is classified under the type III IFN. It is induced by viruses and other IFNs and displays potent antiviral activity against some virus infections in vivo $^{20}$. Acceptance of this classification is less universal than that of type I and type II, and unlike the other two, little is known of this class and lots of investigations are currently ongoing to properly understand it. The type III interferon group consists of four IFN- $\lambda$ (lambda) molecules called IFN$\lambda 1$, IFN- $\lambda 2$, IFN- $\lambda 3$ (also known as IL29, IL28A and IL28B respectively), and IFN $-\lambda 4^{21}$.

\section{CLASSIFICATION}

Type I interferon: Are produced in direct response to viral infection and comprise the products of the IFN- $\alpha$ multigene family, which are predominantly synthesized by leucocytes, and the product of the IFN- $\beta$ gene, which is synthsized by most cell types but particularly by fibroblasts.

Type II Interferon: Consists of the product of the IFN- $\gamma$ gene and, rather than being induced directly by virus infection, is synthesized in response to the recognition of infected cells by activated Tymphocytes and natural killer (NK) cells

Type III interferon: The type III interferons are structurally more closely related to the IL-10 family of proteins than either of the other IFN subtypes, but contribute to antiviral responses and induce activation of many of the same genes as the type I and II IFN molecules. This subtype is poorly understood at this time and has not been studied in graftversus-host disease (GVHD) or graft-versus-leukemia (GVL) responses. Both type I interferons and IFN- $\gamma$ play critical roles in GVHD and GVL 22 .

\section{MECHANISM OF ACTION OF INTERFERON}

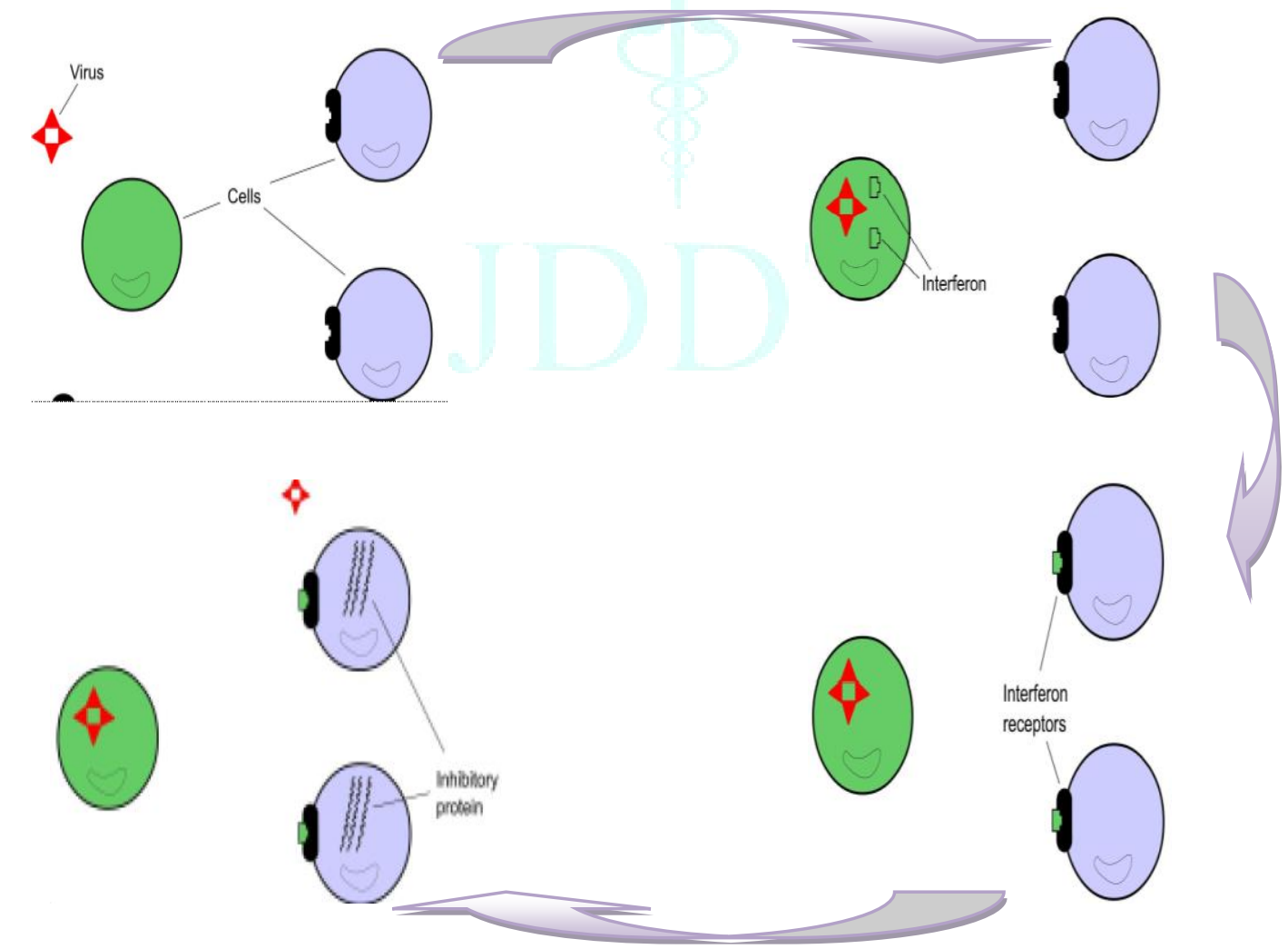

Figure1: Mechanism of action of interferon: Role of interferon starts after an initial viral attack on target cells. Several cell types when infected with virus secrete interferon. The secreted interferon enters the interstitial fluid and blood and binds to interferon receptors. This induces synthesis of inhibitory proteins that inhibit progressive or subsequent viral attack and possible viral replication 


\section{THERAPEUTIC APPLICATIONS AND FUNCTIONS OF INTERFERON}

\section{Antiviral activity}

Significant successes have been achieved in the wide use of recombinant IFN- $\alpha$ forms in the treatment of chronic hepatitis B virus (HBV) and hepatitis C virus (HVC) infections and some forms of cancer ${ }^{23-25}$. IFN- $\beta$ treatment for multiple sclerosis is regularly used to limit exacerbations of the disease $26-28$. IFN- $\gamma$ has been approved for clinical use only in a rare congenital disorder and in chronic granulomatous disease 29,30 .

\section{Antiproliferative and antitumour activities}

Currently, the antiproliferative action, together with its antitumour activity, is one major breakthrough concerning interferon function ${ }^{31-35}$. It is known that IFN- $\alpha$ can act on Tcells causing the differentiation of the T-helper 1 cells, while at the same time inhibiting the growth of other lymphocytes ${ }^{34}$. Similarly, IFN- $\alpha$ can act on NK cells and macrophages, thus enhancing their production of interferon and especially their production of interleukin 1 and their proliferation, thus increasing the number of circulating cells 36 .

Because of their cell differentiation and growth regulatory properties, interferons have been used in attempts to treat neoplasms 37,38 . Several forms of haematological cancers and solid tumours have been treated with interferons with some success $^{33,34}$.

\section{Treatment of multiple sclerosis}

Treatment of multiple sclerosis with IFN- $\beta$ was initiated based on the immunomodulatory properties of the interferon ${ }^{39,40}$. Well-controlled studies have demonstrated that intramuscular treatment with IFN- $\beta$ results in a reduction in the annual rate of relapses of multiple sclerosis ${ }^{41}$.

\section{Signal transduction}

To exert their first messenger activities, IFNs bind to specific membrane receptors. These receptors enables cells sense the external signal of IFN and then transfer it in the interior so that the cell can produce what is known as interferoninducible proteins ${ }^{42}$. Just like the interferons, receptors are classified into two, namely the receptor for IFN- $\alpha$ and IFN- $\beta$ on the one side and the receptor of IFN- $y$ on the other side ${ }^{43}$. The interferon receptors consist of two sub-units. These are transmembrane proteins with an extra-cytoplasmic domain and an intra-cytoplasmic domain displaying particular motifs that bind to proteins which make it possible for this external signal to be sensed within the cell ${ }^{44}$. These receptors are grouped under the JAK proteins, which mainly comprise the tyrosine kinase proteins that can phosphorylate tyrosine residues ${ }^{44}$. The STAT proteins are other important proteins, and they too have dual role; i.e. they act as signal transducers and also as transcription activators ${ }^{45}$. Finally, another group of proteins playing a pivotal role in the interferon signal transduction is composed by the Interferon Regulatory Factors (IRFs), known to act as transcription factors but are still being studied to fully understand their functional roles or mechanisms ${ }^{46,47}$.

\section{SIDE EFFECTS OF INTERFERONS}

Common side effects of Interferons are:

\section{Fever}

Fatigue
Malaise

muscle pains

Cardiorenal toxicity, bone marrow and liver toxicities. 48-50

\section{CONCLUSION}

Interferon is gaining significance based on clinical and laboratory results and the availability of improved molecular technology. Therapeutic application of interferon applications can be envisaged in all areas of biomedical sciences, including molecular biology techniques. Hence the usefulness of interferon continues to expand into the field of medicine, molecular biology, pharmaceutical medicine and biotechnology.

\section{COMPETING INTERESTS STATEMENT}

The authors declare no conflicts of interest.

\section{REFERENCES}

1. Marco Túlio R. Gomes, Daiane M. Cerqueira, Erika S. Guimarães, Priscila C. Campos and Sergio C. Oliveira, Guanylate-binding proteins at the crossroad of noncanonical inflammasome activation during bacterial infections, Journal of Leukocyte Biology. 2019; 106(3):553-562.

2. Kang S, Brown HM, Hwang S. Direct Antiviral Mechanisms of Interferon-Gamma. Immune Network. 2018; 18(5):e33.

3. Raftery N, Stevenson NJ. Advances in anti-viral immune defence: revealing the importance of the IFN JAK/STAT pathway. Cellular Molecular Life Science. 2017, 74(14):25252535

4. Galani IE, Triantafyllia V, Eleminiadou E, Koltsida O, Stavropoulos A, Manioudaki M, Thanos D, Doyle SE, Kotenko $S V$, Thanopoulou K, Andreakos E. Interferon- $\lambda$ Mediates Nonredundant Front-Line Antiviral Protection against Influenza Virus Infection without Compromising Host Fitness. Immunity. 2017 46(5):875-890.e6

5. Beuckelaer AD, Grooten J, Koker SD. Type I Interferons Modulate CD8+ T Cell Immunity to mRNA Vaccines. Trend in Molecular Medicine. 2017; 23(3):216-226.

6. Yang T, Yang Y, Wang D, Li C, Qu Y, Guo J, Shi T, Bo W, Sun Z, Asakawa T. The clinical value of cytokines in chronic fatigue syndrome. Journal of Translational Medicine. 2019; 17:213

7. Hoffmann $\mathrm{HH}$, Schneider WM, Rice CM. Interferons and viruses: an evolutionary arms race of molecular interactions. Trends in Immunology. 2015: 36(3):124-138.

8. De Andrea M, Gariglio M, Gioia D, Landolfo S, Ravera R. The interferon system: an overview. European Journal of Paediatric Neurology. 2002; 6A(6):A41-58.

9. Ivashkiv LB, Kalliolias GD. Overview of the biology of type I interferons. Arthritis Research \& Therapy. 2010; 12(1): S1.

10. De Weerd NA, Samarajiwa SA, Hertzog PJ. Type I interferon receptors: biochemistry and biological functions. Journal of Biological Chemistry. 2007; 282(28):20053-20057.

11. Kursunel MA, Esendagli G. The untold story of IFN- $\gamma$ in cancer biology. Cytokine \& Growth Factor Reviews. 2016; 31:73-81.

12. Parker, B., Rautela, J, Hertzog, P. Antitumour actions of interferons: implications for cancer therapy. Nature Reviews Cancer 2016; 16:131-144.

13. Sang Y, Bergkamp J, Blecha F. Molecular evolution of the porcine type I interferon family: subtype-specific expression and antiviral activity. PLoS One. 2014; 9(11):e112378.

14. Isaacs A, Lindenmann J. Virus interference. I. The interferon. Proceedings of the Royal Society B: Biological Sciences. 1957; 147(927):258-267.

15. Lopušná K, Režuchová I, Betakova T, Skovranova L, Tomašková J, Lukáčiková L, Kabat P. Interferons lambda, new cytokines with antiviral activity. Acta Virologica. 2013; 57(2):171-179.

16. Zaidi MR, Merlino G. The two faces of interferon- $\gamma$ in cancer. Clinical cancer research. 2011; 17(19):6118-6124.

17. Tau G, Rothman P. Biologic functions of the IFN-gamma receptors. Allergy. 1999; 54(12):1233-1251.

18. Niedelman W, Gold DA, Rosowski EE, Sprokholt JK, Lim D, Arenas AF, Melo MB, Spooner E, Yaffe MB, Saeij JP. The 
rhoptry proteins ROP18 and ROP5 mediate Toxoplasma gondii evasion of the murine, but not the human, interferongamma response. PLoS pathogens. 2012; 8(6): 1002784.

19. Kim K, Cho SK, Sestak A, Namjou B, Kang C, Bae SC. Interferongamma gene polymorphisms associated with susceptibility to systemic lupus erythematosus. Annals of the rheumatic diseases. 2010; 69(6):1247-1250.

20. Ank N, West H, Bartholdy C, Eriksson K, Thomsen AR, Paludan SR. Lambda interferon (IFN- $\lambda$ ), a type III IFN, is induced by viruses and IFNs and displays potent antiviral activity against select virus infections in vivo. Journal of virology. 2006; 80(9):4501-4509.

21. Vilcek J. Novel interferons. Nature immunology. 2003; 4(1):89.

22. Markey KA, MacDonald KPA, Hill GR. Cytokines in graftversus-host disease and graft-versus-leukemia. Immune Biology of Allogeneic Hematopoietic Stem Cell Transplantation. 2013; (2013):357-391.

23. Pawlotsky JM, Feld JJ, Zeuzem S, Hoofnagle JH. From non-A, non-B hepatitis to hepatitis $\mathrm{C}$ virus cure. Journal of hepatology. 2015; 62(1):S87-99.

24. Zoulim F, Durantel D. Antiviral therapies and prospects for a cure of chronic hepatitis B. Cold Spring Harbor perspectives in medicine. 2015; 5(4):a021501.

25. Ely A, Arbuthnot P. Differing prospects for the future of using gene therapy to treat infections with hepatitis $B$ virus and hepatitis C virus. Discovery medicine. 2015; 20(109):137-143.

26. Reder AT, Feng X. How type I interferons work in multiple sclerosis and other diseases: some unexpected mechanisms. Journal of Interferon and Cytokine Research. 2014; 34(8):589599.

27. Axtell RC, Raman C, Steinman L. Interferon- $\beta$ exacerbates Th17-mediated inflammatory disease. Trends in immunology. 2011; 32(6):272-277.

28. Killestein J, Polman CH. Determinants of interferon $\beta$ efficacy in patients with multiple sclerosis. Nature reviews Neurology. 2011; 7(4):221-228.

29. Köker MY, Camcıoğlu Y, van Leeuwen K, Kılıç SŞ, Barlan I, Yılmaz M, Metin A, de Boer M, Avcılar H, Patıroğlu T, Yıldıran A. Clinical, functional, and genetic characterization of chronic granulomatous disease in 89 Turkish patients. Journal of allergy and clinical immunology. 2013; 132(5):1156-1163.

30. Marciano BE, Wesley R, De Carlo ES, Anderson VL, Barnhart LA, Darnell D, Malech HL, Gallin JI, Holland SM. Long-term interferon- $\gamma$ therapy for patients with chronic granulomatous disease. Clinical infectious diseases. 2004; 39(5):692-699.

31. Berraondo P, Sanmamed MF, Ochoa MC, Etxeberria I, Aznar MA, Pérez-Gracia JL, Rodríguez-Ruiz ME, Ponz-Sarvise M, Castañón E, Melero I. Cytokines in clinical cancer immunotherapy. British journal of cancer. 2019; 120(1):6-15.

32. Bank S, Andersen PS, Burisch J, Pedersen N, Roug S, Galsgaard J, Turino SY, Brodersen JB, Rashid S, Rasmussen BK, Avlund S. Genetically determined high activity of IL-12 and IL-18 in ulcerative colitis and TLR5 in Crohns disease were associated with non-response to anti-TNF therapy. The pharmacogenomics journal. 2018; 18(1):87-97.

33. Shen J, Xiao Z, Zhao Q, Li M, Wu X, Zhang L, Hu W, Cho CH. Anti-cancer therapy with TNF $\alpha$ and IFN $\gamma$ : A comprehensive review. Cell proliferation. 2018; 51(4):e12441.

34. Dierckx T, Khouri R, Menezes SM, Decanine D, Farre L, Bittencourt A, Vandamme AM, Van Weyenbergh J. IFN- $\beta$ induces greater antiproliferative and proapoptotic effects and increased p53 signaling compared with IFN- $\alpha$ in PBMCs of Adult T-cell Leukemia/Lymphoma patients. Blood cancer journal. 2017; 7(1):e519-.
35. Chiantore MV, Mangino G, Iuliano M, Zangrillo MS, De Lillis I, Vaccari G, Accardi R, Tommasino M, Fiorucci G, Romeo G. IFN$\beta$ antiproliferative effect and miRNA regulation in Human Papilloma Virus E6-and E7-transformed keratinocytes. Cytokine. 2017; 89:235-238.

36. Müller L, Aigner P, Stoiber D. Type I interferons and natural killer cell regulation in cancer. Frontiers in immunology. 2017; 8:304.

37. Padilla-Quirarte HO, Trejo-Moreno C, Fierros-Zarate G, Castañeda JC, Palma-Irizarry M, Hernández-Márquez E, Burguete-Garcia AI, Peralta-Zaragoza O, Madrid-Marina V, Torres-Poveda K, Bermúdez-Morales VH. Interferon-Tau has antiproliferative effects, represses the expression of E6 and E7 oncogenes, induces apoptosis in cell Lines transformed with HPV16 and inhibits tumor growth in vivo. Journal of Cancer. 2016; 7(15):2231-2240.

38. Ningrum RA, Wisnuwardhani PH, Santoso A, Herawati N. Antiproliferative activity of recombinant human interferon alpha2B on estrogen positive human breast cancer MCF-7 cell line. Indonesian Journal of Pharmacy. 2015; 26(2):86.

39. Buttmann $M$, Rieckmann $P$. Interferon- $\beta 1 \mathrm{~b}$ in multiple sclerosis. Expert review of neurotherapeutics. 2007; 7(3):227239.

40. Maier K, Kuhnert AV, Taheri N, Sättler MB, Storch MK, Williams SK, Bähr M, Diem R. Effects of glatiramer acetate and interferon- $\beta$ on neurodegeneration in a model of multiple sclerosis: a comparative study. The American journal of pathology. 2006; 169(4):1353-1364.

41. Limmroth V. The interferon beta therapies for treatment of relapsing-remitting multiple sclerosis: are they equally efficacious? A comparative review of open-label studies evaluating the efficacy, safety, or dosing of different interferon beta formulations alone or in combination. Therapeutic Advances in Neurological Disorders. 2011; 4(5):281-296.

42. Samuel CE. Interferons, interferon receptors, signal transducer and transcriptional activators, and interferon regulatory factors. Journal of Biological Chemistry. 2007; 282(28):20045-20046.

43. De Weerd NA, Nguyen T. The interferons and their receptors-distribution and regulation. Immunology and cell biology. 2012; 90(5):483-491.

44. Au-Yeung N, Mandhana R, Horvath CM. Transcriptional regulation by STAT1 and STAT2 in the interferon JAK-STAT pathway. Jak-stat. 2013; 2(3):e23931.

45. Silver-Morse L, Li WX. JAK-STAT in heterochromatin and genome stability. Jak-Stat. 2013; 2(3):e26090.

46. Zhao GN, Jiang DS, Li H. Interferon regulatory factors: at the crossroads of immunity, metabolism, and disease. Biochimica et Biophysica Acta (BBA)-Molecular Basis of Disease. 2015; 1852(2):365-378.

47. Smith GL, Benfield CT, de Motes CM, Mazzon M, Ember SW, Ferguson BJ, Sumner RP. Vaccinia virus immune evasion: mechanisms, virulence and immunogenicity. Journal of General Virology. 2013; 94(11):2367-2392.

48. George PM, Badiger R, Alazawi W, Foster GR, Mitchell JA. Pharmacology and therapeutic potential of interferons. Pharmacology \& therapeutics. 2012; 135(1):44-53.

49. Shibinskaya MO, Lyakhov SA, Mazepa AV, Andronati SA, Turov AV, Zholobak NM, Spivak NY. Synthesis, cytotoxicity, antiviral activity and interferon inducing ability of 6-(2-aminoethyl)$6 \mathrm{H}$-indolo [2, 3-b] quinoxalines. European journal of medicinal chemistry. 2010; 45(3):1237-1243.

50. Lin FC, Young HA. Interferons: success in anti-viral immunotherapy. Cytokine \& growth factor reviews. 2014; 25(4):369-376. 